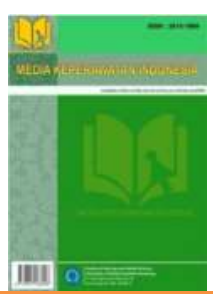

\title{
Increased The Cognitive, Effective, and Psychomotor Aspects of Nurses in The Practice of Developmental Care
}

\author{
Mariyam $^{1}$, Riwayati2 \\ 1,2 Universitas Muhammadiyah Semarang
}

\section{Article Info}

Article History:
Accepted Jan 15th 2018 Key words:
Cognitive
Affective
Psychomotor
Developmental care

\section{PENDAHULUAN}

BBLR menyebabkan tingginya angka kematian karena seringkali mengalami beberapa masalah sebagai akibat dari organ

\begin{abstract}
Background: The cause of high infant mortality rate is low birth weight (LBW). Optimal LBW treatment needed that the baby can pass the transition from intrauterine to extrauterine. One of the efforts done is developmental care. Implementation of developmental care requires knowledge, attitudes and skills of nurses. Objective: This study aims to identify the cognitive, affective and psychomotor aspects of nurses in treating LBW before and one month after being given developmental care information at RS Roemani Semarang. Methodology: The design of this research are pre experiment pre and post design. The sample of the study was all nurses in high risk infant room Roemani Hospital Semarang . Sample amounted to 12 respondents. Researchers identify the cognitive, affective and psychomotor aspects of nurses in treating LBW with questionnaires and observations before being given developmental care information. A month after being given information about developmental care researchers re-identify the cognitive, affective and psychomotor aspects of the nurse. Result: Cognitive score of respondent before health education 11.75 and after 13.83 with total score 22, mean affective score of respondent before health education 48,83 and after 52,92 with total score 60 , mean of psychomotor score of respondent before health education 2.58 and after 4 with a total score of 4 . Based on the results of statistical analysis each show $p$ value 0.00 so that it can be concluded there are differences cognitive, affective and psychomotor nurses in the application of developmental care both before and a month after being given health education. Discussion: In this study post intervention is done month after health education like input from previous researcher Zubaidah, rustina \& Sabri (2013) to know the right time in repeating the same information. The results showed that after 30 days showed a cognitive, affective and psychomotor increase, this could be because after given the health education nurses apply in the care of LBW so that knowledge and skills increase.
\end{abstract}

Corresponding author:

Mariyam

mariyam@unimus.ac.id

Media Keperawatan Indonesia, Vol 1 No 1, February 2018

e-ISSN: 2615-1669

DOI:10.26714/mki.1.1.2018.20-26

yang belum matang. Surfaktan yang kurang dan sedikitnya alveoli yang berfungsi mengakibatkan bayi kesulitan bernapas (Bobak, Lowdermilk \& Jersen, 2005). Selain itu BBLR juga berisiko terjadi 
ketidakseimbangan suhu, hipoglikemia, asfiksia, ketidakseimbangan cairan elektrolit, hiperbilirubinemia, infeksi dan gangguan pertumbuhan serta perkembangan (University of California San Fransisco children Hospital, 2004).

Berbagai masalah yang dihadapi BBLR menyebabkan bayi membutuhkan perawatan yang intensif. Bayi membutuhkan berbagai prosedur dan fasilitas peralatan untuk mendukung kelangsungan hidup bayi. Walaupun hal tersebut dibutuhkan bayi, namun pada kenyataannya beberapa prosedur dan fasilitas perawatan merupakan stresor sendiri bagi bayi. Stres tersebut bersumber dari kebisingan yang dihasilkan dari alat monitor, percakapan staff di ruang perawatan, prosedur invasif misalnya pengambilan sampel darah, pergantian popok, membuka dan menutup inkubator, dan perpisahan orang tua (Westrup et al, 2000; Lissauer \& Fannarof, 2009). Selain itu pencahayaan ruangan juga merupakan sumber stres bayi (Bowden et al, 2009).

Stres pada bayi akan mengeluarkan energi yang seharusnya dibutuhkan untuk pertumbuhan dan perkembangan. Oleh karena itu dibutuhkan strategi perawatan untuk mengurangi stimulus yang berlebihan. Strategi tersebut dapat dicapai melalui asuhan perkembangan atau developmental care. Intervensi developmental care antara lain modifikasi lingkungan (penerangan dan suara), minimal handling, perawatan metode kanguru, pemberian posisi tepat, pengelompokan aktifitas perawatan dan memfasilitasi interaksi bayi dan orang tua (Bowden et al, 2009).

Banyak penelitian yang menunjukkan manfaat developmental care. Pemberian posisi prone dapat menurunkan kehilangan panas. kanguru mother care dapat meningkatkan saturasi oksigen (Ali et al, 2009). Penelitian yang dilakukan Ludwig et al (2008) menunjukkan bahwa developmental care dapat mempercepat kenaikan berat badan bayi prematur dan mempercepat kepulangan.

Manfaat developmental care pada BBLR sangat membantu agar bayi dapat tumbuh dan berkembang secara optimal, sehingga perlu diterapkan di ruang perawatan bayi. Beberapa intervensi developmental care di RS Roemani sudah diterapkan di neonatal intensive care unit (NICU) yaitu penerapan minimal handling. Namun intervensi lain belum dilaksanakan dengan maksimal. Sedangkan di ruang perawatan bayi risiko tinggi, intervensi developmental care belum diterapkan. Pemberian informasi terkait kanguru mother care pernah diberikan, namun belum diterapkan. Hal inilah yang melatarbelakangi peneliti ingin mengidentifikasi terkait kognitif, afektif dan psikomotor perawat dalam merawat BBLR baik sebelum dan sesudah diberikan pemberian informasi developmental care. Zubaidah, Rustina \& Sabri (2012) telah meneliti pengaruh pemberian informasi developmental care terhadap pengetahuan, sikap dan tindakan perawat dalam merawat BBLR di RS dr Karyadi Semarang. Penelitian ini hanya meneliti sebelum dan sesaat setelah intervensi dan pada saran penelitian lanjut diharapkan meneliti efek jangka panjang informasi yang diberikan. Oleh karena itu penelitian ini meneliti kognitif, afektif dan psikomotor setelah sebulan intervensi.

Tujuan dari penelitian ini untuk mengetahui pengaruh pendidikan kesehatan tentang developmental care terhadap kognitif, afektif dan psikomotor perawat dalam merawat BBLR.

\section{METODE}

Penelitian ini adalah penelitian eksperimen semu (quasy experiment) dengan jenis pre and post test design. Populasi penelitian ini adalah perawat ruang bayi risiko tinggi RS Roemani Semarang. Sampel ditentukan dengan teknik total sampling, yaitu dengan mengambil semua anggota populasi menjadi responden sesuai dengan kriteria 
inklusi. Kriteria inklusi responden meliputi: perawat ruang bayi risiko tinggi, perawat tidak sedang cuti, bersedia menjadi responden dengan jumlah sampel 12 responden.

Sebelum diberikan intervesi pemberian informasi, responden diidentifikasi terlebih dahulu kognitif, afektif dan psikomotor dalam merawat BBLR. Kognitif dan afektif perawat diukur dengan kuesioner yang diadopsi dari Zubaidah, Rustina \& Sabri (2012) dengan validitas 0,3 dan reliabilitas sebesar 0,855 artinya instrumen dinyatakan valid dan reliabel. Pemberian informasi diberikan dengan metode ceramah, diskusi, demonstrasi dan praktik klinik. Total waktu pemberian informasi 15 jam, merujuk pada penelitian yang dilakukan oleh Mohamed dan Wafa (2011). Setelah pemberian informasi selesai, dilakukan identifikasi kognitif, afektif dan psikomotor perawat dalam merawat BBLR 30 hari kemudian.

\section{HASIL}

Responden dalam penelitian ini berjumlah 12 dengan rerata usia 37,08 tahun (SD \pm $6,403)$ dan rerata lama bekerja 6,92 tahun (SD \pm 6,388). Pendidikan responden 11 dari DIII dan 1 dari S1 Ners dan berdasarkan paparan terhadap informasi terkait developmental care sejumlah 4 responden sudah pernah mendapatkan informasi dan 8 responden belum pernah mendapatkan informasi tentang developmental care. Rerata kognitif perawat tentang developmental care sebelum diberikan pendidikan kesehatan 11,75 dan sesudah 13,83 dengan total skor 22, rerata skor afektif responden sebelum pendidikan kesehatan 48,83 dan setelah 52,92 dengan skor total 60, rerata skor psikomotor responden sebelum pendidikan kesehatan 2,58 dan setelah 4 dengan total skor 4 .
Tabel 1. Distribusi responden berdasarkan kognitif, afektif dan psikomotor dalam penerapan developmental care pada perawatan BBLR sebelum diberikan pendidikan kesehatan di RS Roemani Semarang

\begin{tabular}{crcc}
\hline Variabel & Mean & SD & $\begin{array}{c}\text { Minimum- } \\
\text { maksimum }\end{array}$ \\
\hline Kognitif & 11,75 & 3,696 & $5-18$ \\
\hline Afektif & 48,83 & 4,407 & $44-59$ \\
\hline Psikomotor & 2,58 & 0,669 & $2-4$ \\
\hline
\end{tabular}

Tabel 2. Distribusi responden berdasarkan kognitif, afektif dan psikomotor dalam penerapan developmental care pada perawatan BBLR Sebulan setelah diberikan pendidikan kesehatan di RS Roemani Semarang

\begin{tabular}{crrc}
\hline Variabel & Mean & SD & $\begin{array}{c}\text { Minimum- } \\
\text { maksimum }\end{array}$ \\
\hline Kognitif & 13,83 & 3,68 & $8-20$ \\
\hline Afektif & 52,92 & 3,825 & $4-60$ \\
\hline Psikomotor & 4 & 0,0 & $4-4$ \\
\hline
\end{tabular}

Berdasarkan hasil analisis statistic masingmasing menunjukkan $p$ value 0,00 sehingga dapat disimpulkan ada perbedaan kognitif, afektif dan psikomotor perawat dalam penerapan developmental care baik sebelum dan sebulan setelah diberikan pendidikan kesehatan.

\section{PEMBAHASAN}

Responden pada penelitian ini adalah perawat yang bekerja di ruang bayi risiko tinggi atau NICU dengan usia antara 29 tahun sampai dengan 49 tahun. Berdasarkan rentang usia responden tersebut merupakan usia produktif untuk bekerja. Sesuai dengan pengertian usia produktif menurut Depkes (2009), yang menyatakan bahwa usia produktif adalah penduduk dengan usia 15 sampai dengan 64 tahun. Hasil penelitian Zubaidah (2012) juga menunjukkan bahwa perawat yang bekerja di ruang NICU adalah usia 22 tahun sampai 56 tahun yang merupakan usia produktif juga. 
Lama bekerja responden berkisar antara 1 tahun sampai dengan 23 tahun dan variasi lama bekerjanya cukup tinggi yaitu 6,388 tahun. Hal ini dikarenakan kebijakan dari rumah sakit yang melakukan rotasi setiap 1 atau 2 tahun. Namun tidak semua perawat yang telah bekerja di ruang bayi risiko tinggi di rotasi ke ruang lain. Sebanyak 7 $(58,3 \%)$ perawat sebagai responden tidak dilakukan rotasi dan telah bekerja lebih dari 5 tahun di ruang bayi risiko tinggi atau NICU.

Pada penelitian ini, perawat yang bekerja di ruang bayi risiko tinggi atau NICU RS Roemani sebagian besar masih berpendidikan DIII keperawatan dan hanya 1 yang sudah Ners. RS Roemani memiliki kebijakan bahwa minimal pendidikan perawat yang dapat bekerja di RS Roemani adalah DIII Keperawatan. Sebagian besar responden $66,7 \%$ belum pernah mendapatkan informasi tentang developmental care dalam perawatan bayi berat badan lahir rendah (BBLR). Hal ini karena ada beberapa responden $41,6 \%$ lama kerja di ruang bayi kurang dari 5 tahun dan belum mendapat kesempatan diikutkan pelatihan atau seminar terkait developmental care.

Kognitif atau pengetahuan merupakan hasil "tahu" dan yang terjadi setelah seseorang melihat terhadap suatu obyek tertentu (Notoatmojo, 2010). Penerapan developmental care membutuhkan pengetahuan terkait hal tersebut dalam pelaksanaan pada perawatan bayi (Coughlin, Gibbins, \& Hoath, 2009). Pada penelitian ini pengetahuan perawat sebelum dilakukan pemberian informasi tentang developmental care menunjukkan skor rata-rata 11,75 dengan total skor 22 . Responden mengetahui bahwa BBLR merupakan bayi dengan berat badan lahir kurang dari 2500 gram tanpa memandang usia gestasi dan mengetahui bahwa bayi yang stress salah satu tandanya tangan dan kaki ekstensi, mengetahui sumber kebisingan yang mempengaruhi bayi adalah menutup incubator, alarm dari alat NICU dan pembicaraan petugas. Responden juga telah mengetahui salah satu cara untuk mengatasi stress bayi adalah dengan menurunkan pencahayaan ruang dan kebisingan dan mengetahui bahwa tindakan untuk mengatur penerangan di NICU dengan memberikan siklus penerangan, menutup bagian atas incubator dan meminimalkan penerangan dari prosedur yang dilakukan pada bayi lain. Pengetahuan responden ini dikarenakan sejumlah 33,3\% responden telah menerima informasi terkait dengan developmental care sebelumnya.

Pada penelitian ini masih terdapat responden yang tidak mengetahui tentang maksud dari developmental care dan tujuan developmental care. Sebagian responden masih ada yang beranggapan bahwa developmental care hanya dilakukan pada saat kondisi bayi dalam keadaan stabil. Masih terdapat responden yang tidak mengetahui kebisingan yang direkomendasikan oleh AAP dan efek dari kebisingan untuk bayi. Responden juga masih belum mengetahui posisi terbaik untuk memfasilitasi perkembangan BBLR yang di rawat di ruang NICU atau perinatologi, belum mengetahui nesting sebagai pembatas untuk mengurangi stres bayi dan belum mengetahui tindakan yang mendukung asuhan perkembangan bayi. Hal ini kemungkinan dikarenakan sebagian besar responden belum pernah mendapatkan informasi terkait developmental care. Rerata kognitif responden setelah sebulan diberikan pemberian informasi 13,83 mengalami penambahan dibanding sebelum diberikan informasi. Pada rentang sebulan setelah diberikan informasi tentang developmental care, responden menerapkan developmental care pada perawatan seharihari bayi berat badan lahir rendah. Hal ini menyebabkan pengetahuan responden bertambah. Menurut Millete, Richard, dan Martel (2005), mengungkapkan bahwa program pelatihan dengan salah satunya memberikan informasi dapat meningkatkan pengetahuan perawat dalam merawat bayi. 
Pemberian informasi developmental care berpengaruh meningkatkan pengetahuan perawat tentang developmental care dalam perawatan BBLR (Zubaidah, Rustina \& Sabri, 2012).

Selain pengetahuan, afektif perawat atau sikap perawat dalam penerapan developmental care pada perawatan BBLR juga dilihat dalam penelitian ini. Sikap merupakan respon tertutup individu terhadap stimulus tertentu, yang sudah melibatkan faktor pendapat dan emosi yang bersangkutan (Notoatmojo, 2010). Ratarata skor afektif responden sebelum diberikan informasi 48,83 dengan total skor 60. Sebagian besar responden setuju dengan melakukan asuhan perkembangan (developmental care) dapat meningkatkan pemberian asuhan perkembangan pada BBLR, menganggap hal itu menyenangkan dan positif. Sebagian besar responden tidak setuju bahwa dengan pendekatan asuhan perkembangan tidak akan memperbaiki pelayanan asuhan keperawatan, selain itu responden juga tidak setuju jika penerapan asuhan perkembangan itu cukup sulit, tidak setuju jika asuhan perkembangan dianggap kurang bermanfaat untuk keluarga dan bayi yang dirawat dan responden juga tidak setuju jika dengan melakukan asuhan perkembangan di NICU atau perinatologi akan membuat dokter atau petugas kesehatan lain kurang mendukung perawat. Hal tersebut menunjukkan sikap perawat terhadap penerapan developmental care pada perawatan BBLR di rumah sakit cukup baik.

Sikap atau kepercayaan mengacu pada ideide yang dimiliki seseorang. Sikap dapat tepat atau tidak tepat. Sikap yang tepat dapat meningkatkan praktek sementara sikap yang tidak tepat dapat memiliki efek yang merugikan, hal tersebut sesuai dengan pendapat Nishaja, Bajacharya dan Shankar (2013). Sikap perawat setelah diberikan informasi mempunyai rerata 52,92. Responden yang sebelumnya merasa bahwa asuhan perkembangan merupakan tindakan yang menyita waktu cukup banyak setelah diberikan informasi anggapan tersebut telah berubah. Pada penelitian ini sikap perawat dalam penerapan developmental care sangat sesuai dengan penelitian Van der pal, et al (2007) mengenai pendapat staf terkait developmental care menunjukkan bahwa perawat memiliki sikap lebih positif terhadap penerapan developmental care dibandingkan dengan staf medis.

Psikomotor merupakan tindakan atau praktek yang ditunjukkan oleh seseorang. Psikomotor responden pada penelitian ini diobervasi 2 kali pada awal responden berinteraksi dengan BBLR dalam memberikan asuhan keperawatan dan pada akhir shif saat responden memberikan asukan keperawatan pada BBLR. Skor ratarata psikomotor responden adalah 2,16 dengan total skor 4. Semua responden telah memberikan posisi fleksi dalam merawat BBLR dan mengumpulkan beberapa tindakan yang memungkinkan dalam satu waktu atau memegang bayi setiap 2-3 jam. Namun ada sebagian responden yang belum menutup bagian atas inkubator dengan kain penutup atau selimut dan belum memberikan nesting atau pembatas pada bagian bawah dan samping untuk mempertahankan posisi bayi. Telah diketahui bahwa penerapan developmental care dapat membantu BBLR untuk tumbuh dan berkembang. Berdasarkan Bowden et al (2000) mengungkapkan bahwa posisi yang tepat dan anatomis adalah komponen penting dalam pemberian asuhan perkembangan pada bayi. Asuhan perkembangan pada bayi dapat diberikan dengan memfasilitasi interaksi antara bayi dan keluarga, pemberian posisi dan nesting, melindngi kulit, meminimalkan stress terhadap nyeri, pemberian nutrisi yang optimal dan menfasilitasi tidur bayi. Praktek developmental care dalam merawat BBLR di RS Roemani telah dijelaskan dalam standar asuhan keperawatan yang ada di rumah sakit namun belum ada standar prosedur yang jelas terkait developmental careI sehingga masih ada perawat yang belum memberikan asuhan perkembangan secara maksimal. Perawat telah 
memberikan pembatas pada bayi namun hanya pada samping kanan dan kiri tubuh bayi bukan melingkari tubuh bayi. Pemberian pembatas ini dimaksudkan untuk memfasilitasi bayi agar tetap dalam kondisi fleksi agar bayi tidak mengalami stres. Psikomotor responden pada penelitian ini sebagian telah baik dikarenakan sikap dari responden terhadap penerapan developmental care juga baik. Nishaja, Bajacharya dan Shankar (2013) dalam penelitiannya menjelaskan sikap yang tepat dapat meningkatkan praktek seseorang. Namun masih ada yang belum menerapkan developmental care hal ini berkaitan dengan penelitian Brown \& Mainous (2009) yang menunjukkan masih banyak perawat yang tidak menerapkan pengetahuan yang telah diperoleh terkait developmental care dalam asuhan perkembangan pada neonatus. Setelah diberikan informasi tentang penerapan developmental care pada BBLR menunjukkan bahwa rerata psikomotor perawat baik, semua responden melakukan penerapan developmental care pada perawatan BBLR.

Pemberian informasi dilakukan dengan metode ceramah, diskusi, demonstrasi dan praktik klinik. Total waktu pemberian informasi 15 jam, merujuk pada penelitian yang dilakukan oleh Mohamed dan Wafa (2011).

\section{SIMPULAN}

Kognitif, afektif dan psikomotor responden dalam penerapan developmental care pada perawatan BBLR setelah 30 hari diberikan informasi mengalami peningkatan dibanding dengan sebelum diberikan informasi. Hal ini bisa menjadikan acuan untuk Rumah Sakit bahwa setelah 30 hari pemberian informasi kognitif, afektif dan psikomotor masih menunjukkan peningkatan sehingga untuk pengulangan pemberian informasi dengan tema yang sama memungkinkan untuk dilakukan setelah 30 hari, tidak perlu diulang dalam waktu kurang dari 30 hari.

\section{REFERENSI}

Ali, S.M., Sharma, J., Sharma, R., \& Alam, S. (2009). Kangoro mother care as compaired to conventional care for LBW bebies. Dicle Med J, 36(3), 155-160.

Bobak, I.M., Lowdermilk, D.L., \& Jasen, M.D. (2005). Buku ajar keperawatan maternitas (edisi 4). Jakarta: EGC

Bowden, V. R., Greenberg, C. S., \& Donaldson, N. E. (2000). Developmental care of the newborn. Online Journal of Clinical Innovation, 3 (7), 177.

Brown, T., \& Mainous, P.O. (2009). Research abstract: understanding staff nurses experiences when implementing neonatal developmental care. Advance in Neonatal Care, 9(4), 186-187.

Coughlin, M., Gibbins. S., \& Hoath, S. (2009). Core measure for developmentally supportive care ini neonatal intensive care unit: theory, precendence, and practice. Journal of Advanced Nursing, 65(10), 2239-2248 UCSF Children's hospital. (2004). Very low and extremely low birth weight infants. Diunduh tanggal 3 April 2016 dari http://www.childinfo.org

Depkes RI. (2009). Data Penduduk sasaran program pembangunan kesehatan 2007-2011. Jakarta: Pusat Data dan Informasi Depkes RI.

Ludwig, S., Steichen, J., Khoury, J., \& Krieg, P. (2008). Quality improvement analysis of developmental care in infant less than 1500 grams at birth. Newborn \& Infant Nursing Reviews, 8(2), 94-100.

Mhilettle, I.H., Richard, L., \& Martel, M.J. (2005). Evaluation of developmental care training program for neonatal nurse. Journal Child health Care, 9, 94-109.

Mohamed, S.A., \& Wafa. A.M. (2011). The effects of an educational program on nurses knowledge and practice related to hepatitis $\mathrm{C}$ virus: $\mathrm{A}$ pretest an

Nishaja, Bajracharya, O., \& Shankar, P.R. (2013). Knowledge, attitude and Practice toward medicine among school teacher in Lalitpur destrict, Nepal before and after educational intervention. BMC Publich Health, 13, 565

Notoatmojo, S. (2010). Promosi kesehatan. Teori dan aplikasi. Jakarta: Rineka cipta 
Van Der Pal et al. (2007). Staff opinions regarding the newborn individualized developmental care and assessment program (NIDCAP). Early Human Development, 83, 425-432

Westrup, B., Kleberg, A., Eichwald, K. V., Stjernvist, K.I., \& Lagercrantz, H. (2000). A randomized controlled trial to evaluation the effect posttest quasi experimental design. Australian
Journal of Basis and Aplied Sciences, 5(11), 564-570

Zubaidah, Rustina, Y., \& Sabri, L. (2013). Peningkatan pengetahuan perawat melalui pemberian informasi tentang developmental care. Paper presented at 10 th international Seminar on Disaster Jogjakarta. 